\title{
Too close for comfort: direct address and the affective pull of the confessional comic woman in Chewing Gum and Fleabag
}

Article

Accepted Version

Woods, F. (2019) Too close for comfort: direct address and the affective pull of the confessional comic woman in Chewing Gum and Fleabag. Communication, Culture and Critique, 12 (2). pp. 194-212. ISSN 1753-9129 doi:

https://doi.org/10.1093/ccc/tcz014 Available at https://centaur.reading.ac.uk/81363/

It is advisable to refer to the publisher's version if you intend to cite from the work. See Guidance on citing.

To link to this article DOI: http://dx.doi.org/10.1093/ccc/tcz014

Publisher: Oxford University Press

All outputs in CentAUR are protected by Intellectual Property Rights law, including copyright law. Copyright and IPR is retained by the creators or other copyright holders. Terms and conditions for use of this material are defined in the End User Agreement.

www.reading.ac.uk/centaur 
Central Archive at the University of Reading

Reading's research outputs online 


\section{Too Close for Comfort: Direct address and the affective pull of the confessional comic woman in Chewing Gum and Fleabag.}

\section{Abstract}

The 2010s saw a boom in television comedies, created by, written, and starring women, that exploring the bawdy and chaotic lives of protagonists who were experiencing some form of arrested development. These comedies sought to build intimate connections with their imagined audiences by crossing boundaries social, bodily and physical - to produce comedies of discomfort. Drawing in part on Rebecca Wanzo's consideration of 'precarious-girl comedy' (2016) I examine how two British television comedies intensified these intimate connections through the use of direct address, binding the audience tightly to the sexual and social misadventures of their twenty-something female protagonists. Michaela Coel's Chewing Gum (E4, 2015-2017) follows naïve and desperately horny black working-class Londoner Tracey in her quest for sexual experience, and PhoebeWaller Bridges' Fleabag (BBC Three, 2016-) documents an unnamed upper-middleclass white woman's sharply misanthropic journey through grief. In both programmes direct address serves to intensify the embrace of bodily affect and intimate access to interiority found in the 'precarious-girl comedy' (Wanzo, 2016), producing moments of comic and emotional repulsion. Each programme uses direct address's blend of directness and distance to different ends, but both draw audiences at times uncomfortably close to the singular perspective of their protagonists, creating an intensely affective comic intimacy. 
Keywords: Direct address, comedy, gender, television, affect, precarity

\section{Too Close for Comfort: Direct address and the affective pull of the confessional comic woman in Chewing Gum and Fleabag.}

A twenty-something black woman in long plaits and a bright jumper kneels next to her boyfriend as he prays with sonorous self-regard, biting her lip with desire as she gazes at his mouth. The camera cuts to her in profile and her gaze wanders to meet the camera, she smiles a polite smile and tipping her head to us, she begins to speak. A twenty-something white woman with sharp red lipstick and curly bobbed hair stands in profile staring at her front door in the dim light of night, dressed in a navy mac. She waits, gasping for breath, then pauses, she turns her head to look to the camera and begins to speak.

Chewing Gum (E4, 2015-2017) and Fleabag (BBC Three, 2016-) open with their protagonists decisively fracturing the suture of the fourth wall. This establishes a privileged relationship between protagonist and viewer as the women break their connection with narrative action and turn to speak to us. This direct address evokes whispered feminine confidences, a shared intimacy, although both women speak with a comic bluntness. Amy Villarejo describes television as a "conduit of affective value" (2013, p. 158), and this article explores how direct address intensifies the 
affective connections and challenges of what Rebecca Wanzo terms the "precariousgirl comedy". Drawing on direct address's ability to blend distance and closeness, I explore how the device builds a complex relationship with the comic abjection that is central to this strand of television comedy. Both programmes use the device to enfold us in their protagonists' perspectives, in an at-times uncomfortably close embrace. I illustrate how a detailed focus on aesthetics can develop insights into the affective work of comedy, particularly a strand so invested in women's physicality and interiority.

I use 'we' and 'us' throughout this article instead of 'the viewer', to signal the affective work of the programmes, as they seek to interpellate the female viewer. My linguistic choice evokes the closeness constructed by their intimate address, and positions myself as an example of their intended audience. Fleabag's protagonist opens her introductory monologue with "You know when...", aligning herself with the female viewer as she describes the panicked labour of femininity needed to produce her pose of casual glamour. This positions these comedies - written, created by and starring women - as women targeted media, as they provide intimate attention to the sometimes comic, sometimes emotionally-fraught struggles of what Rebecca Wanzo terms “the precarious-girl” (2016). These programmes are not only watched by women, but the affective pull of their comedy can offer a particular intertwining with female audiences. I am aware that as a white British woman close to these programmes' target demographic (both aired on British channels that target 16-34 year olds), I cannot speak for all audiences. This 'us' may have the ring of critic 
Emily Nussbaum's notorious championing of Girls (HBO, 2012-2017) as “for us, by us", presented without any interrogation of who this 'us' was (Nussbaum, 2012; Wanzo, 2016, p. 27). As Hollis Griffin notes, television can produce a breadth of interactions with programming, producing "experiences that are both psychic and corporeal, as much thought as they are felt" $(2017$, p. 72$)$. I recognise that affective responses are individual and diverse, (2017, p. 73) and often ephemeral. However, despite these issues I use 'us' and 'we' as an attempt to communicate the tight grasp that these programmes' aesthetic and storytelling choices encourage.

I build here on a wealth of recent scholarship that has explored the representations and comic discomforts displayed in a transatlantic strand of femaleled comedies produced in the 2010s. The critical mass of these comedies generated an at-times intense cultural discourse about their affective embodiment of female experience, which is reflected in the investments of this scholarship. (Benson-Allott, 2017; Filippo, 2016; Havas \& Sulimma, 2018; Lagerwey \& Nygaard, 2018; Perkins, 2014). This comic boom was catalysed by the success of HBO's Girls, which dominated certain sections of cultural discourse (Woods, 2015). Following Girls came Broad City (Comedy Central, 2014-) (whose web series predecessor (2009-11) actually preceded Girls) , You're the Worst (FX/FXX, 2014-), Casual (Hulu, 2015-2018), Difficult People (Hulu, 2015-2017), Love (Netflix, 2016-2018), Insecure (HBO, 2016-) (and Issa Rae's web series predecessor The Misadventures of Awkward Black Girl (YouTube, 2011-2013)), Divorce (HBO, 2016-), Lady Dynamite (Netflix, 2016-2017) and I Love Dick (Amazon Video, 2016-2017). Chewing Gum, Fleabag and Catastrophe (Channel 4, 2015-) 
joined from the UK (although the latter two were co-productions with US streaming giant Amazon), with UnReal (Lifetime/Hulu, 2015-2018) and Crazy Ex-Girlfriend (The CW, 2015-2019) (the sole network representative here) offering hour-long interpretations. ${ }^{1}$

I take up Rebecca Wanzo's concept of the 'precarious-girl comedy' as a descriptor for this strand of comedies. Through an analysis of Girls and the web series The Misadventures of Awkward Black Girl (Awkward Black Girl hereafter), Wanzo suggests that the precarious-girl comedy makes the endless alienation of its millennial female subject a source of humour $(2016,29)$. Marshalling abjection as an important affective mode (2016, p.33) these programmes built "deeply reflexive representations of women and failure" (2016, p. 53). As I discuss below, this strand of 2010s 'precarious-girl' comedies signified a shift in television comedy's engagement with women's voices and identity. They deployed an intimate experience of comic abjection as a mode of emotional 'authenticity' and comic freedom, mobilised in response to a generation's post-recessionary economic immobility and social confusion.

Direct address intensifies the comic abjection and affective intensity of the 'precarious-girl comedy', which revels in shame, desire, disgust, pain and joy. By focusing on the affective impact of Chewing Gum and Fleabag's aesthetic and

\footnotetext{
${ }^{1}$ Many of these programmes have been grouped by Jorie Lagerway and Taylor Nygaard under the banner of 'horrible white people', a 'representational trend as intimately tied to recession, the emergent mainstreaming of feminism(s), the unmasked visibility of racial inequality and violence, and changes in TV \roduction and distribution models'. (Lagerwey \& Nygaard, 2018)
} 
storytelling devices, I illustrate how the "the screen is a join that amplifies affect and connects' the viewer with characters" (Kavka, 2014, p. 37). The simulated eye-contact produced by direct address intensifies this join, reducing "the gap between one's own face and others" (2014, p. 37). This is an intimate gaze, and this intimacy is compounded by the access given to our protagonists' bedrooms and bathrooms. At times this intimacy and its binding of us to these women's comic abjection pulls us too close encouraging a comic or emotional discomfort. In moments such as these, these programme's comic affect can feel more like the 'force' that Eugenie Brinkema identifies, one "that does not have to move from subject to object. But may fold back, rebound, recursively amplify" (Brinkema, 2014, p. 24). Direct address enfolds and assimilates the viewer into these women's comic abjections, amplifying the intimate connections of the precarious-girl comedy and its "hybrid affect of discomfited pleasure" (Wanzo, 2016, p. 27).

Both Chewing Gum and Fleabag use direct address to "appeal to our agreement or complicity" in their protagonists' actions (Brown, 2013, p. 122). However, it is important to note that they offer differing interpretations of the 'precarious-girl' and analysing them together illustrates how race and class can impact the representation of the figure. Bright, warm and bawdy, Chewing Gum chronicles black working-class Londoner Tracey's thirst for sexual experience. We occasionally escape the grasp of Tracey's perspective to glimpse the experiences of other members of Chewing Gum's comic ensemble (although they do not share her privileged access to us through direct address). Tracey's sheltered religious upbringing has left her with the social 
confusion and desperate horniness of a hormonal teenager. Her awkward physicality and confused desires are embodied in her chattering, effusive overflow of direct address, which illustrates her lack of emotional and physical control. Where Chewing Gum is warm, Fleabag is cool. Angular and angry it revels in sly comic cruelties as it follows an unnamed upper-middle-class white woman's (I refer to her as 'Fleabag' throughout) embrace of promiscuity as part of her stumbling and misanthropic journey through grief following the death of her best friend. Fleabag traps us solely in the perspective of its emotionally-detached protagonist, where direct address is used to display her performance of femininity and attempts to control social situations. Flashes of emotion escape this facade, signalling that underneath this display she feels as intensely and chaotically as Tracey.

Both programmes construct a multi-layered viewing stance, where we examine both the narrative action and our protagonists' interpretations of it (Birke \& Warhol, 2017, p. 152). Their direct address varies in intensity and narrative control: from a wordless connection of the gaze within a scene; to a snatched aside that briefly breaks a diegetic conversation; to a turn to camera for introduction or explanation; to a full scale 'live' narration of a scene. This constructs an intricate dance of closeness and detachment that constantly shifts our engagement with narrative action, bouncing between "complicity and distance" (Caughie, 1991, p. 150).

Having established the frame for this analysis, I now move to identify the 
preoccupations of the precarious-girl strand of television comedy, and the specificities of Chewing Gum and Fleabag's British context. I then explore some of these programmes' affective investments in more detail, demonstrating how direct address compounds the impact of their comic and bodily intimacies, drawing the viewer uncomfortably close.

\section{Situating the Precarious-Girl}

Drawing on Wanzo's analysis, I identify the 'precarious-girl comedy' as a string of single-camera comedies on cable and streaming platforms that centralise emotional intensity and chaotic comedy in their charting of contemporary femininity. Encompassing the experience of twenty-something to forty-something women, these include female-led ensembles as well as mixed-gender casts that offer a strong investment in the perspective of their female characters (You're the Worst, Casual, Love, Divorce). They often offer "unlikeable heroines who make their series' political interventions more complex by disrupting viewers' sympathies" (Benson-Allott, 2017, p. 66). Wanzo suggests that these comedies are characterised by "the nexus of abjection and precarity" in a post-recessionary landscape (2016, p.29). These predominantly-white middle-class protagonists have experienced unexpected financial and social precarity, leading them to struggle with and embrace physical and emotional abjection. Many of these precarious-girl comedies feature a female creator-writer-star, drawing a "strategically thin line between the author-performer's 'enacted' and 'real' self" (Havas \& Sulimma, 2018, p. 5), that foregrounds female voice and infers authenticity of experience. 
The precarious-girl comedy is the latest iteration in the lengthy history of the single-girl comedy. This sub-genre has responded to shifting social understandings of women's identity, ranging from That Girl (ABC, 1966-1971) and The Liver Birds (BBC1, 1961-1979, 1996) to Sex and the City (HBO, 1998-2004), through to The Mindy Project (FOX/Hulu, 2012-2017). The precarious-girl comedy presented a performative rejection of the aspirational postfeminist glamour that had dominated the previous generation of single girl stories in film and television, embodied by Sex and the City. It also offered a decisive shift from the gently unruly (Kathleen Rowe Karlyn, 1995) US network sitcoms that debuted across 2011-2012, including The Mindy Project and New Girl (FOX, 2011-2018).

The precarious-girl comedy centres on arrested protagonists and insular, dysfunctional relationships, and an at times stark questioning of identity. It encourages "fluctuating viewing positions that alternate between laughter, uneasiness, and frustration" (Havas \& Sulimma, 2018, p. 2). Wanzo suggests that it "evolves from comedic traditions that utilize abjection", including stand-up comedy and Kathleen Rowe Karlyn's (2003) figure of the "unruly woman" (2016, p. 29). A figure that unsettles patriarchal standards of appropriate feminine humour, the unruly woman is "considered excessive - too fat, too mouthy, too old, too dirty, too pregnant, too sexual (or not sexual enough) for the norms of conventional gender representation" (Kathleen Rowe Karlyn, 2003, p. 253). A valuable model for exploring comic women, the unruly woman has nevertheless become something of a 
theoretical straight-jacket. Overused culturally to the point of abstraction (Petersen, 2017), it has become the wearing default frame through which to discuss women in comedy. As both Chewing Gum and Fleabag demonstrate, female identity can have a more complicated and nuanced relationship with comic debasement, beyond the rebellious, liberatory rhetoric that the unruly woman has mutated into within pop culture discourse. In the precarious-girl comedy the bawdy power of the unruly woman shades more strongly into shame, alienation and insularity as a response to economic and social precarity. Welcoming us into bedrooms and bathrooms with a blunt familiarity, they entangle audiences (whether willing or not) with their floundering female protagonists. They take pleasure in crossed boundaries - social, emotional and physical - to produce comedies of "discomfited pleasure" (Wanzo, 2016, p. 27) that shade shame into disgust.

This strand forms part of a larger international comic investment in 'cringecomedy' (Middleton, 2014) across film and television, often focalised around the arrested development of male-dominated ensembles and authors. From the misanthropic debauchery of Its Always Sunny in Philadelphia (FX/FXX, 2005-) to the tentative awkwardness of Please Like Me (ABC2/Pivot, 2013-16). The precarious-girl comedy gained much of its comic power by shaping a vision of complicated and disruptive femininity through a frame that had long been naturalised as masculine.

\section{British Comic Contexts}

Chewing Gum and Fleabag are clearly part of an international televisual zeitgeist 
invested in comic female identities. The inescapable cultural bombast of Girls arguably impacted television commissioning in the UK as it did in the US. But as Justine Ashby notes, "we should not assume that [these discourses] can simply be grafted onto the rather different contours of British political and popular culture" (2005, p. 128). Positioning Chewing Gum and Fleabag within British comedy and representational contexts can problematise tendencies that read the precarious-girl as a disruptive, revolutionary comic force (Nussbaum, 2012). Critical discussions have tended to present US middle-class representations as a norm, which has helped to assimilate Fleabag uncritically into US discussions of the strand of precarious-girl comedy (Burbridge, 2017; Havas \& Sulimma, 2018; Lagerwey \& Nygaard, 2018) (as has its status as an Amazon co-production). It is interesting that Chewing Gum has been less easily incorporated into this discourse, perhaps due to its black, workingclass identity amongst a sea of middle-class, largely white, women.

Both programmes saw critical success when exported to the US via streaming platforms, Fleabag on Amazon and Chewing Gum on Netflix, where it was claimed falsely as a 'Netflix Original'. ${ }^{2}$ This critical success mirrored their reception in the UK, where both Coel and Waller-Bridges won BAFTAs for their performances, and both shows were nominated for the BAFTA for Best Scripted Comedy. The precarious-girl has tended to be positioned as prestige comedy (Havas \& Sulimma, 2018; Lagerwey \& Nygaard, 2018), yet both were produced for British youth channels owned by public service broadcasters. As I have argued elsewhere, British

\footnotetext{
${ }^{2}$ Their success with US audiences is harder to quantify thanks to these SVODs' refusal to produce viewing figures
} 
youth television asserts its distinction from US teen television through an embrace of the mundane, a plainness of speech and frank sexuality (Woods, 2016), all qualities frequently attributed to the precarious-girl comedy. Sitcoms populated with mundane lives, casual cruelty, crude humour and comedies of embarrassment were familiar on Chewing Gum and Fleabag's British homes. These included the schoolboys of E4's The Inbetweeners (E4, 2008-2010) and the flatmates and young couples of E4's Drifters (2013-2016) and BBC Three's Two Pints of Lager and a Packet of Crisps (20012011) and Him \& Her (2010-2013). The anti-glamour, interpersonal cruelties, selfish protagonists and embrace of sexual abjection that were framed as revolutionary in Girls (Nussbaum, 2012) had already been a feature of Pulling (BBC Three, 2006-2009), Sharon Horgan's bleak comedy of female friendship. Fleabag and Chewing Gum were presented as quietly revolutionary in British press, but it is important to note that the ordinariness and mundanity, alienation and immobility that the US cycle offers up as confrontational and exceptional is a British comic norm.

Tracey's position as a working-class black woman also needs to be contextualised here, as all the above sitcoms feature white casts and Chewing Gum represents a rare black-authored and led sitcom in British television. ${ }^{3}$ While I discuss Tracey in tandem with Fleabag, she diverges from the white middle-class norm of the precarious-girl comedy, where abjection is a rebellious stance or product of

\footnotetext{
${ }^{3}$ British television has historically lacked black-authored sitcoms with Lenny Henry's range of comedies and Trix Worrell's Desmonds (Channel 4, 1989-1994) relatively lonely outposts (Malik, 2001; Osborne, 2016). While it targeted a younger audience, Levi David Addai's Youngers (E4, 2013-14) tread similar comic council estate ground as Chewing Gum, and BBC Three recently debuted Kayode Ewumi's Enterprice (2018) about a pair of bumbling aspiring twentysomething entrepreneurs.
} 
economic shock. Tracey's abjection is not a choice but is created by her social and sexual naiveté that is catalysed by her emergence from her evangelical upbringing. As I note below, Chewing Gum's comic ensemble is contextualised within British film and television's representational practices surrounding working-class life. Through her race and class Tracey is doubly coded with difference. In part, she illustrates Wanzo's assertion that race complicates abjection's offer of freedom for the middleclass millennial subject (2016, p. 29). Wanzo suggests that the black precarious-girl cannot revel in abasement, abjection and 'grossness' like her white peer. This is because "abjection haunts black bodies as a representational shadow" (2016, p. 45) through racist stereotypes of the black grotesque produced through cultural histories built from white supremacy.

Instead Wanzo argues that Awkward Black Girl creator Issa Rae constructed "an alternative, less pathologized framework of reading the black body" by positioning "awkwardness as the height of black abjection" (2016, p.46). However, transatlantic alignments between Tracey and the awkwardness displayed by the black protagonists of Awkward Black Girl and Insecure (Rae's glossy HBO series that eventually followed) are disrupted by Chewing Gum's fondness for comic excess. The awkwardness of Rae's US black protagonists is largely contained to their narration and moments of fantasy. However, Tracey's comic physicality and blunt direct address intensifies her awkwardness into an affective overflow that constantly teeters on the edge of abjection. 
Wanzo suggests that the 'avowedly awkward abject subjectivity' of Awkward Black Girl's protagonist shifted from the abjection that Girls revelled in, placing her within traditions of mainstream sitcoms (2016, p.50). In a similar way, Chewing Gum's abjection links with both British representational practices surrounding the working-classes and British comic traditions of abject comic ensembles. This context somewhat naturalises the programme's play with comic grotesquery, defusing its potential links with racial stereotypes. Paul Abbot's long-running (largely white) ensemble comedy-drama Shameless (Channel 4, 2005-2013) exists in a venn diagram of traditions of British working-class representation and abject comic ensembles. It offered a bawdy comic warmth and edge of the surreal in its celebratory depiction of the community of a deprived Manchester council estate (Creeber, 2009; Johnson, 2013). Like Shameless, the community of Tracey's estate is framed with considerable warmth. But as a rare working-class black creative in British television (which Coel highlighted whilst delivering the prestigious 2018 keynote address to the Edinburgh International Television Festival (Coel, 2018)), Coel took great pains to position Chewing Gum outside of dominant representations of struggle and violence in black working-class communities, found across politics and popular culture (for example, Bullet Boy (Dibb, 2004), Kidulthood (Clarke/Huda, 2006) and Top Boy (C4, 2011-2013)). The programme was intentionally filmed in summer (Lewis, 2017), flooding Tracey's council estate with bright high-keyed colours and window boxes full of plants. Wide shots centralised the open space that the estate's balconies open onto, with establishing shots set to a background of children's laughter, depicting a welcoming, open community. 
Chewing Gum centralises Tracey's perspective through her direct address, but it expands its comic abjection across the estate's diverse community. This aligns with British sitcom traditions of abject ensembles, from Father Ted (Channel 4, 1995-1998) to Pulling to The Inbetweeners. Tracey is not the only precarious-girl on the estate: her best friend Candice complains in the middle of the grocery store about her unfulfilled desire for rough sex, and Tracey's repressed sister Cynthia orgasms at her first glimpse of porn, and later gets drunk on liquors and vomits them into her lap. Awkward Black Girl and Insecure lessen the power of the 'historical weight of black abjection' (Wanzo, 2016, p. 30) by shifting abjection and "cringe comedy" onto J and Issa's white co-workers (Havas \& Sulimma, 2018, p. 14). Similarly, Chewing Gum delights in white grotesquery. This includes the mother of Tracey's boyfriend who demands a horrified internet hook-up feed her baby food as she role-plays as a baby in a dirty onesie (S1E2), and the upper-class woman with 12 Years a Slave (McQueen, 2013) sexual fantasies and a mouth encrusted with cold sores that Tracey recruits for a threesome with her boyfriend (S1E4). These women can be read through British comic traditions and push beyond the 'gross' physicality of the precarious-girl. By revelling in an ensemble of abject femininities, Chewing Gum helps to lessen the pathologizing of Tracey's abjection.

However, her direct address intensifies our experience of Tracey's comic abjection. As the only character who speaks to us (asides from a moment her cousin 'Boy Tracey' launches into his own direct address (S1E5)), we are bound tighter to 
her struggles. We experience Tracey's comic abjection in close-up, continually looped into her overflowing desires and failures at appropriate social performance. Having positioned Chewing Gum and Fleabag within the investments of precariousgirl comedy and their British context, I now delve into their affective practices in more detail, beginning with Tracey and Fleabag's positions of precarity and stasis.

\section{Precarity, Immobility and Interiority}

Both Tracey and Fleabag experience arrested development - economic, emotional and psychological. This produces the perpetual girlhood of immobility and isolation that Wanzo identifies in the precarious-girl comedy (2016, pp. 28-29). Tracey's sheltered upbringing leads her to display a confusion and desperate horniness more common to a hormonal teenager than the mid-twenties woman she is. Her frustration at her stasis - both social and sexual - overflows through her direct address and is compounded by Michaela Coel's performance of an effusive but deeply awkward physical comedy that borders on comic abjection. Desperate to lose her virginity, and suffused with intense desire, Tracey is bewildered by sex. In her first clueless attempt at sexual intimacy at a party she licks and sucks her partner's nose, ears and hair before taking Candice's advice and sitting on his face, still clad in her pyjamas and training bra.

Fleabag is similarly arrested. She is grieving the death of her best friend Boo, but flashbacks show that even before this stasis, she had struggled to take herself seriously and 'grow up' (E5). The failing cafe she once shared with Boo is an 
archetypal illustration of post-recessionary white-middle-class economic precarity, the site where her psychological and economic precarity intertwine. Suffused with her memories of Boo's warmth and compassion, in the present it stands cold and quiet, empty of customers. Fleabag's direct address is a symptom of her current inability to make the emotional connections necessary for an embrace of adulthood. She struggles to connect with or confess herself to family or partners, which puts her at a constant ironic remove from her life. Her alienation is communicated through the pose of emotional control and manipulation she performs through her direct address.

Fleabag's grief is in familiar company with the precarious-girl comedy's preoccupation with mental illness and emotional distress (Lagerwey \& Nygaard, 2018); from Hannah's OCD in Girls, to Rachel's (perhaps) bipolar disorder in UnReal, Gretchen's chronic depression in You're the Worst, Micky's addictive personality in Love and so on. This preoccupation with emotional instability interweaves with the strand's fondness for deriving pleasure and discomfort from its access to character interiority. This investment in protagonists' skewed perspectives extends to the use of non-naturalistic devices to communicate female interiority. Awkward Black Girl's confessional voiceover and Insecure's daydreams and fragments of rap delivered to bathroom mirrors (and in turn the camera) allows their protagonists 'to live through [their] frustration or desire without repercussions' while maintaining a reserved exterior (Havas \& Sulimma, 2018, p. 12). Fragments of fantasy in Broad City and I Love Dick align us with their protagonists' skewed perspective, which Lady Dynamite 
pushes to surreal extremes in a bid to embody the experience of mental illness. Similarly invested in exploring its protagonist's mental instability, the musical numbers of Crazy Ex-Girlfriend offer their own form of direct address, naturalised by genre conventions. These instances of non-naturalism serve the strand's complicated - and at times illusionary - assertion of emotional transparency and intimate access to its protagonists.

Chewing Gum and Fleabag's direct address continue this intimate experience of female interiority that blends emotional truth and self-deception. In both programmes direct address signals authentic expression, as we hear what no one else can. But at the same time it showcases both women's lack of understanding of self, drawing on the device's role as "a particularly rich metaphor for [characters'] problems of vision" (Brown, 2013, pp. 166-167). Both Fleabag and Tracey perform transparency and enclose us into their perspective, yet we realise that neither woman truly knows themselves. Thus, direct address helps embodying their position as precarious girls. I now move further into detailing how this use of direct address intensifies intimate comic discomfort.

\section{The Intimate Gaze}

The scaffolding of narratives around the singular connection of direct address signals both programmes' development from theatre monologues written by their stars. In adapting these for television both women expand the singular focus of their monologues into comic ensembles, but use direct address to retain the affective, 
intimate pull the theatre pieces. Dorothee Birke and Robyn Warhol characterise televisual direct address as an adaptation of a theatrical device (2017, p. 151), however, I view these programmes' use of direct address as a distinctly televisual presence, particularly in its construction of and reliance on television's inherent intimacy.

Direct address and breaking the fourth wall is normalised in factual television through its use of presenters, however the form is very rare in drama. Alan Bennet's Talking Heads (BBC2, 1988, 1998) offered extended 30 minute to-camera monologues and BBC2's Murder (2016) interwove testimonies of suspects, victims, police and lawyers to unravel the events surrounding a murder. Both programmes were performed entirely in direct address, naturalising what is a non-naturalist device. Their storytelling drew on the form's combination of transparency and deception (of self and others), and its ability to place audiences on unstable footings through its encouragement of complicity with a speaker. This complicity was central to BBC1's House of Cards (BBC1, 1990) and its Netflix remake (2013-2018). Here direct address was used within otherwise naturalistic political melodramas, in order to make the audience complicit with "their protagonists' cynicism and criminal intent" (Birke \& Warhol, 2017, p. 151).

In television fiction, the sitcom is the more natural home of direct address, due to the genre's roots in comic performance. The British multi-camera sitcom has seen scattered use of the comic aside or extended direct address monologue, 
including Up Pompeii (1969-1970), Sean's Show (Channel 4, 1992-1993), Miranda (BBC2/BBC1, 2009-2015) and the surprisingly reflexive Mrs Brown's Boys (BBC1, 2011-). Here to-camera address draws on the multi-camera's performance style playing to both the camera and the live studio audience - and the stand-up and comedy theatre roots of many of these creator-stars. But the mockumentary format is the dominant space for direct address in single-camera comedy (Middleton, 2014). Here the to-camera reaction shot and the mock-interview serve as central comic devices. However, outside of mockumentary, direct address is rare in the singlecamera sitcom.

Both Fleabag and Chewing Gum use the device's novelty and non-naturalism to weave their intimate comedies of discomfort. Direct address within naturalistic narratives provokes discomfort as "[t]he actor's aside to "you" seems to pierce the boundary of the television screen and enter the viewer's domestic space" (Birke \& Warhol, 2017, p. 153). Boundary piercing is a particularly evocative description of Fleabag and Chewing Gum's comic and emotional invasion of the viewer, using direct address to construct an intimate physicality. The space between ourselves and the protagonist is erased, drawing us in through a brief moment of eye-contact, an aside or a defined turn.

Both women's turn to camera is frequently a deliberate, performative movement, physicalising each programme's intimate address. They exist on two distinct planes of action: contained within narrative action, but also separated and 
connected with us through their gaze, as action pauses or carries on oblivious to their interaction with us. Their confessions are at times at odds with the actions they are engaged in, particularly their casual (Fleabag) or panicked (Tracey) address to us during sexual activity. This produces an at times intense discomfort through their sharing of awkward or abject emotions, whilst they perform (poorly in Tracey's case) composed femininity with their partners.

Direct address intensifies the affective experience of the precarious-girl comedy, enfolding us into a "state of heightened anxiety as we anticipate the unfolding of excruciating encounters on-screen" (Wanzo, 2016, p. 37). As Tom Brown notes, the device embodies ambiguity, as its non-naturalism produces distance and disruption but it also has capacity for intimacy (2013, p. 177). This ambiguity is key to the abject affect of the precarious-girl comedy, unsettling an audience who do not know quite how they should react to protagonists' violations of social and cultural taboos (Havas \& Sulimma, 2018, p. 9). I now move to explore these programmes' physicality and their investment in these violations, through their intimate access to abject bodies.

\section{Abject Bodies and Intimacies}

The precarious-girl comedy is preoccupied with breaking social and emotional taboos surrounding femininity, bodies and sexual experience, producing the intimacy and emotional rawness central to its interpellation of its female audience. Many of these comedies embrace the intense physicality that Claire Perkins 
identifies in Girls, which uses bodies to convey its affective power (2014, p. 34). This particular blend of intimacy and physical abjection is embodied in the figure of the woman on the toilet, underwear around her knees. Wanzo asserts that the precarious-girl's associations with that "which is considered gross (like dirt, vomit, and feces) is habitually a sign of what emotional and economic insecurity has wrought" (2016, p. 29). Yet these recurring toilet scenes also signal our intimate access to characters. They present as mundane what has previously been coded as abject, deriving a frisson of comic rebellion from depicting the socially taboo, private and 'gross' on screen.

Marnie and Jess talk while the latter uses the toilet in Girls (S1E1) and Broad City opens season four with a split-screen time-lapse of months in the life of Abby and Illana, depicted through mirrored locked-down shots of their respective toilets. Both sequences signal female intimacy, although the Girls scene offers an underlying power struggle symbolised by each woman's posture on the toilet. Similarly, Fleabag and Chewing Gum signal our intimate access to their protagonists by having each directly address us whilst using the toilet, during an act even more televisually intimate than sex. In Season 1 episode 2 Tracey is panicked and convinced she is pregnant after her boyfriend ejaculates on her thigh. Having prayed to God and Beyoncé after taking a fake 'folk' remedy (drinking a can of Coke and rubbing haemorrhoid medication on her stomach), she sits on the toilet, tightly framed from above within the tiled walls of the small room. She pulls out toilet paper bright with period blood from between her legs and the camera cuts to a frontal medium close- 
up as she looks to us delightedly. Exclaiming "You gotta have faith, yo", she drops the paper on the floor and raises her hands and face to the sky with a bright smile. The moment is played for comic fantasy with heavenly light from above and a gospel chorus, before crash cutting to her best friend Candice cackling scornfully at Tracey's belief in the fake 'remedy'. In season 1 episode 2 Fleabag delivers an extended monologue whilst sat on the toilet, knickers around her knees. She casually ponders her pleasure in the performance and awkwardness of sex, and the power she derives from others desire. The scene ends with her grabbing the last piece of toilet paper and cuts as she stands up in front of the camera to wipe herself. The intimacy of direct address is entwined with our discomfort at being addressed during the mundane, normally private, activity. Both scenes are symbolic of each programme's relationship with abjection; Chewing Gum derives its discomfort from its cringing bodily excesses, Fleabag's from its complicated blend of comic thrill and emotional detachment.

We take on the role of both women's friends in these moments. But this access extends beyond the spaces of friendship as they interpellate us into their sexual activity. Eyes will flicker to us amidst a kiss, turn for an anguished or smug glance, or address us bluntly during sex acts. This direct address compounds the depiction of sex as comically awkward and at times abject, rather than erotic. Both programmes derive comic discomfort from their forcing of this sexual intimacy. This is signalled in the sequences that open both programmes, which combine a blunt direct address with a comic sexual excess to signal Tracey's overflowing desire and 
Fleabag's performance of emotional control. After Tracey turns to us and attempts a performative femininity with a bright smile, she shifts to a brash bluntness to introduce herself. Her flat, disgruntled pronunciation of her name - which she complains "sounds like I eat bacon sarnies or have sex at the back of the bus" - and her screwed up face emphasises her comic disgust at its (and her own) ordinariness. Shortly afterwards, when the camera has moved to a frontal position as her partner, Ronald, continues to pray, we are drawn into Tracey's desirous gaze through pointof-view shots of his crotch. Suddenly we are thrown into her fantasy of their passionate embrace, the intensity of her sexual desire communicated in a furious montage of sharp angles and hyper-sexual $r \& b$. But this desire is presented as comic excess through Tracey's awkward physicality: she moans with delight as she licks Ronald's eyebrows, bites his hair and sucks his nose.

In contrast with Tracey's comically overflowing desire, the opening of Fleabag blends desire with control as its protagonist talks us plainly through her late-night booty call. Her opening "You know when..." suggests an alignment with the female viewer, the familiarity of her detailed description of the labour involved in constructing this opening image of effortless sexiness in response to a 2am booty call. She continues narrating the action in direct address as the man arrives, pausing only for his brief dialogue and their kiss, the action entirely framed through her perspective. We cut immediately to the couple in bed in the middle of sex, she glances to us over her shoulder with a smile as she bounces on top. We then cut to the side, as they lay on the bed, her face and body turned to us as he carries on 
behind, oblivious to our presence. She talks us through his 'thrilled' delight at her drunk, casual acceptance of anal sex. After wincing as he penetrates her, she stares wide eyed at us as he continues, continuing our connection during the sex act. Both openings delight in drawing us close whilst simultaneously shocking and potentially repelling us through this intimate access to their protagonists' interiority.

Throughout the series, Fleabag entangles us in her sexual abjection, taking pleasure in the shock value of her embrace of sexual debasement and her blend of desire and detachment. Later in the episode she recalls through flashbacks how she masturbated to Barack Obama speeches whilst her boyfriend slept beside her and how youthful she felt when she had sex with a grotesque old man. Wanzo suggests the precarious-girl embraces abjection as an expression of authenticity (2016, p. 29). Flebag's abject confessions signal her direct address as transparent, in contrast to the unstable performance of controlled upper middle-class femininity she presents to others. We alone have access to her authenticity.

Where Fleabag revels in her sexual abjection Tracey has an ambiguous relationship her own. Like Hannah in Girls, Tracey's comic abjection is derived from her lack of boundaries. However, where Hannah's actions derive from her narcissism (Wanzo, 2016, p. 43), Tracey's are the result of her naiveté and lack of sexual knowledge, her arrested development. As she lacks the control learned through teenage socialisation her desperate thirst for sexual experience catapults her full throttle into abjection. A 24 year-old virgin, her pent-up sexual desire physically 
overloads her body, causing her nose to bleed during sexual dreams and when Conor takes her top off for the first time at a party (S1E1). She pauses, embarrassed, pads her nose with tissues, then barrels through this 'gross' bodily abjection, desperate to escape her perpetual girlhood. Tracey's frequent address to us during her eager but fumbling attempts at sex acts with Conor creates an uncomfortable intimacy, we cannot gain distance from her naivité and intensely awkward physicality. When she attempts her first hand-job her face fixes into an angry rictus through the effort of her aggressive and painfully fast-paced grasp (S1E2), and her uncomfortable attempts at dirty talk shift from factual description to garish talk of broken bum cheeks (S1E4).

Tracey overshares her swirl of emotions, blending fear and desire in a chattering, confused comic overflow. In contrast, Fleabag's abjection is signalled through her detachment from the emotions involved in her embrace of taboo acts. Fleabag uses sex to avoid recognising her emotional instability, and masturbation figures her detachment; sex presented as a selfish act. During dull missionary sex with her sensitive, boring boyfriend, she locks eyes with us rather than him (S1E2). As he thrusts ever so gently she ponders to us how she "masturbates a lot these days" when "bored, or angry, or upset, or happy", inferring but not recognising her sexual compulsion. As she talks to us she reaches down and interrupts their penetrative sex to masturbate, to his confusion. She then turns her full focus to her own sexual pleasure, pushing him gently off of her, then more aggressively slapping away his attempts to touch her, closing her eyes to dedicate herself to her orgasm. 
She takes pleasure in forcing the connection of the direct address with us during her masturbation, making us share a private act. Throughout the series she divorces sex from emotion, but progressively it is revealed this sexual abjection is a selfdestructive rather than empowering act.

I have demonstrated how both programmes use direct address to extend their narrative and aesthetic investment in the precarious-girl's abject physicality, particularly the comic abjection of sexual intimacy. I shift now to explore how direct address serves divergent expressions of control and social performance. This builds into a detailed discussion of a climactic scene in Fleabag's season 1 finale, which weaves direct address into a complex display of affective force.

\section{Access, Complicity and Control}

Direct address conventionally infers agency and power, a story knowledge (Brown, 2013, pp. 13-14), but in Chewing Gum and Fleabag it can offer divergent representations of control, contributing to the 'discomforting pleasure' (Wanzo, 2016, p. 27) of the precarious-girl comedy. Tracey confesses her desire for agency in her own life, linking her quest for sexual knowledge with self-fulfilment. Her direct address illustrates her constant questioning of herself and those around her, her thoughts explode in a scattered overflow that signals her lack of control. In contrast Fleabag performs social mastery through her direct address. Deftly able to read and understand social cues and constructs, she is always a step ahead, predicting for us how her sister, her ex-boyfriend and her family will react to her actions. 
Fleabag's direct address signals her constant social performance, her attempts to conceal her own moments of flailing, frustration and fury. As she narrates situations moment to moment, she is constantly enfolding us into her detached perspective and casual cruelties. Fleabag performs this direct address as if it is confessional, but instead it is conspiratorial. The sexual and social confidences she shares show her construction of identity and her manipulation; flirting with a stranger on a bus or seeing just how far she can push her super-sensitive boyfriend. Fleabag uses her direct address to claim power over the story, when in her life she has none. She spirals through economic failure, complicated family dynamics and self-destructive grief. Throughout the series she returns - in flashbacks suffused with emotional warmth - to the life and death of her best friend Boo. But she conceals her own destructive role in the events preceding Boo's accidental suicide. This forms part of Fleabag's control over her interactions with us, carefully maintaining the boundaries of what she will let us experience, concealing the root of her self-loathing. When flickers of a particular flashback break through - hands hurriedly undoing a man's jeans in the soft glow of a lamp, a glass of red wine perched nearby - she halts them abruptly, telling us "not for now" (S1 E4).

The show's narrative is built around the loss of female intimacy and comfort that Boo embodies, and further in Fleabag's past, her mother. Boo is progressively exposed as the gaping hole at the heart of Fleabag. Glimpsed in flashback Boo is rumpled, warm and soulful, softening Fleabag's sharpness and misanthropy 
through the friends' intimate connection. In all her interactions with Boo, Fleabag is physically demonstrative and expressive, she is casual and slightly sloppy in her movement. The friends croon at each other in profile in the warm evening light of their cafe, improvising a song about abortion and cake, gazing into each other's eyes over red wine and cigarettes. Boo holds Fleabag's face in her hands, a tight unit separate from the outside world (S1 E1). Fleabag's present is cold and lacks emotional intimacy, her uptight sister recoils at physical contact and her father is awkwardly distant. Her family expresses awkward, repressed, concern about her emotional state, yet keep her at arms-length. Fragments of her emotional instability emerge: the man she is dating reveals to her family that they met when he found her crying in the toilets at a bar (E5), and she explains to her bank manager, (a virtual stranger who is himself broken and desperate to return to his family) that "I just wanna cry, all the time" (E4). She does not share these emotions with us, instead her pain flickers through the performance of control deployed through her direct address.

Fleabag's grief over her role in Boo's death propels the self-destructive behaviour that her direct address presents as sexual freedom. As season 1 develops Fleabag becomes a story about processing shame and grief. She can only do that by detaching from her direct address, as her relationship with us offers her last shred of control. We replace Boo as her co-conspirator against the world, but we do not return Fleabag's address, and do not offer the warmth that Boo once did. Fleabag interpellates us in place of human connection, but this intimate access is ultimately 
revealed as a performance.

Both programmes use the confessional qualities of direct address to create an ambivalent relationship with control. As direct address can also expose a "failure of insight" (Brown, 2013, p. 122), disparities between their direct address and narrative action at times undercut Tracey and Fleabag's shaping of the narrative. Tracey's awkward attempts at swagger are undercut in the moment. Season 1 episode 3 opens with an extended monologue as she reclines confidently on a bench, her arms outstretched, complaining about how boring the estate is, "there's not even crime here". Yet the wide shot shows her friends operating a heist behind her in the background, deceiving police to steal large bags from a flat (later revealed to contain a collection of comically huge dildos). Tracey's performance of streetwise confidence - she explains that her mind is 'bare agile' - is entirely at odds with what we've learnt of her so far in the season. The sequence draws comedy from its display of her lack of power and "failure of insight", depicted through the divergence between her failed performance for us and the action that occurs around her.

Fleabag's narrative control falls away - along with her direct address - as the season 1 reaches its climax. She is progressively cut down as the season moves into its final third, when family members proffer harsh truths and she is repeatedly chastened. At first these moments see her turn to us with a smile, seeking to repel or defuse her shame by moving from the interpersonal connection within the scene to a relationship she can control. Yet her smug smile to us flickeringly falters, exposing 
her performance of confidence control as a falsity papering over the cracks in her sense of self. When she is truly embarrassed about her behaviour she refuses to meet the camera's (and our) gaze. These moments create fractures in her control of the viewer's experience that ultimately shatters in the finale.

Direct address becomes sparse in the season finale, we now observe her, instead of being enfolded into her perspective. A series of events at the opening of her stepmother's art exhibit shake her sense of self and expose her "failure of insight" (Brown, 2013, p. 122). Both her sexual partners surprise her by choosing other women, when she'd convinced herself they were in love with her. Her stepmother triumphs in their season-long power-struggle and her father confronts Fleabag in public over her bad behaviour. The affective climax of the season sees her sister Claire choose to believe her husband's lie over Fleabag's earlier claim that he tried to kiss her. This event catalyses Fleabag's breakdown, as Claire coldly notes that how could she believe Fleabag "after what you did to Boo".

The comment triggers a sequence that unfolds in an affective overflow as Fleabag's betrayal of Boo is finally revealed to us. The power dynamics of her direct address shift as her control over our relationship is shattered. A tearful and panicked Fleabag flickers her gaze between us and Claire, and the sisters are then triangulated with flashbacks of a distraught Boo staring towards the camera in a series of accusatory shot-reverse-shots. Our intimate connection with Fleabag is unmoored, as we are interpellated into Boo's and Claire's hurt instead, forced to confront the 
cruelty we had taken pleasure in. The angular, atonal jazz score that previously appeared in sharp bursts (figuring the painful messiness of Fleabag's hidden emotions) now overwhelms the soundtrack as she becomes trapped in the camera's - and by extension our - accusing gaze. The power relationship reverses as she tries to avoid the camera, stumbling backwards fearfully as it advances towards her. Fragments of her memories of Boo and Boo's boyfriend are cross-cut with the camera's pursuit. Trapped in a dark corner Fleabag cowers, confronted by these memories and our gaze. The cross-cutting spirals into a montage of flashbacks: of Boo talking of her love for her boyfriend, and Fleabag drunkenly kissing him and undoing his jeans. The latter is the memory that she'd refused to share with us before in episode 4, as it exposes her betrayal of Boo. In flashback, Boo stares directly into the camera, producing an affective overflow as she pours out her distress at her boyfriend's betrayal with an unknown woman. The editing constructs this as a shotreverse shot with Fleabag's present-day shamed glances to camera. Boo rambles her confused plans to hurt herself to get her boyfriend's attention and we see her final step into the busy road outside their cafe. In this sequence Fleabag's grip on our experience of the narrative is broken, her memories overflow and take precedence. She is exposed and confronted by her selfish betrayal of Boo, and her guilt over her role in Boo's death is revealed, her sexual abjection here exposed as a cruel betrayal rather than an empowering freedom. When she later makes her final confession in an outpouring of her pain and fears, it is to her bank manager, not to us. Her direct address is completely absent in this concluding scene, we are not the focus of this cathartic moment of honesty and true transparency. Instead the bank manager takes 
Boo's place in the cafe, repeating her earlier assurance that "people make mistakes". We are freed from Fleabag's grasp as she finally makes a human connection.

\section{Conclusion}

This article has explored the power dynamics and intimacy of direct address offered by Chewing Gum and Fleabag, demonstrating the device's role in their comedies of abjection and discomforting pleasures. Despite its potentially broad audience, I have suggested that the precarious-girl comedy serves as women targeted media, because the power of its comic abjection is drawn from the intimate and affective bonds it builds with its female audiences. The direct address in Chewing Gum and Fleabag intensifies these affective practices and the precarious girl's interpellation of female viewers (Wanzo, 2016, p. 33). In places this shifts beyond pleasurable recognition, as the tight embrace of direct address becomes too much, we are drawn too close. Locked eyes with the protagonists we have no escape as we are drawn into sexual intimacies and emotional abjection. The singular focus and affective force of direct address punctures the screen and intensity of this connection becomes too close for comfort.

\section{Bibliography}


Ashby, J. (2005). Postfeminism in the British frame. Cinema Journal, 44(2), 127-133. https:/ / www.jstor.org/stable/3661101

Benson-Allott, C. (2017). No such thing not yet: Questioning television's female gaze. Film Quarterly, 71(2), 65-71. 10.1525/fq.2017.71.2.65

Birke, D., \& Warhol, R. (2017). Multimodal you: Playing with direct address in contemporary narrative television. In J. Alber, G. Olson, \& B. Christ (Eds.), How to do things with narrative: Cognitive and diachronic perspectives (pp. 141155). Walter de Gruyter GmbH \& Co KG.

Brinkema, E. (2014). The forms of the affects. Durham: Duke University Press.

Brown, T. (2013). Breaking the fourth wall: Direct address in the cinema. Edinburgh: Edinburgh University Press.

Burbridge, R. (2017, August 28). The rise of the television-comedy auteur. The New Yorker. Retrieved from https:/ / www.newyorker.com/magazine/2017/09/04/the-rise-of-thetelevision-comedy-auteur

Caughie, J. (1991). Adorno's reproach: repetition, difference and television genre. Screen, 32(2), 127-153. https://doi.org/10.1093/screen/32.2.127

Coel, M. (2018, August 23). Michaela Coel: MacTaggart lecture in full. Retrieved December 20, 2018, from https://www.broadcastnow.co.uk/broadcasters/michaela-coel-mactaggartlecture-in-full/5131910.article 
Creeber, G. (2009). 'The truth is out there! Not!': Shameless and the moral structures of contemporary social realism. New Review of Film and Television Studies, 7(4), 421-439. https://doi.org/10.1080/17400300903306995

Filippo, M. S. (2016). “Art porn provocauteurs": Queer feminist performances of embodiment in the work of Catherine Breillat and Lena Dunham. The Velvet Light Trap, 77(1), 28-49. muse.jhu.edu/article/609053

Griffin, H. (2017). Evaluating television: Affect as a critical optic. Cinema Journal, 57(1), 71-93. 10.1353/cj.2017.0056

Havas, J., \& Sulimma, M. (2018). Through the Gaps of My Fingers: Genre, Femininity, and Cringe Aesthetics in Dramedy Television. Television $\mathcal{E}$ New Media, Online First, 1-20. https://doi.org/10.1177/1527476418777838

Johnson, B. (2013). “The fantastic style of Shameless.” In S. Peacock \& J. Jacobs (Eds.), Television aesthetics and style (pp. 227-238). London: Bloomsbury Publishing. Karlyn, Kathleen Row. (2003). Roseanne: Unruly woman as domestic goddess. In J. Morreale (Ed.), Critiquing the sitcom: A reader (pp. 251-261). Syracuse, New York: Syracuse University Press.

Karlyn, Kathleen Rowe. (1995). The unruly woman: Gender and genres of laughter. Austin, Tex: University of Texas Press.

Kavka, M. (2014). A matter of feeling: Mediated affect in reality television. In L. Ouellette (Ed.), A companion to reality television (pp. 460-477). Chichester: John Wiley \& Sons.

Lagerwey, J., \& Nygaard, T. (2018). Liberal women, mental illness, and precarious whiteness in Trump's america. Flow, 24(03). Retrieved from 
https://www.flowjournal.org/2017/11/whiteness-in-trumps-america/

Lewis, T. (2017, January 8). Chewing Gum's Michaela Coel: 'I enjoy making people uncomfortable.' Guardian. Retrieved from https://www.theguardian.com/tvand-radio/2017/jan/08/michaela-cole-enjoy-making-people-uncomfortablechewing-gum-season-two

Malik, S. (2001). Representing black Britain: Black and Asian images on television. London: SAGE.

Middleton, J. (2014). Documentary's awkward turn: Cringe comedy and media Spectatorship. Abingdon, Oxon: Routledge.

Nussbaum, E. (2012, March 25). It's different for “Girls.” Retrieved August 27, 2014, from http:/ / nymag.com/arts/tv/features/girls-lena-dunham-2012-4/

Osborne, D. (2016). Black British comedy: Desmond's and the changing face of television. In J. Kamm \& B. Neumann (Eds.), British TV comedies: Cultural concepts, contexts and controversies (pp. 167-182). London: Palgrave Macmillan UK.

Perkins, C. (2014). Dancing on my own: Girls and television of the body. Critical Studies in Television, 9(3), 33-43. https://doi.org/10.7227/CST.9.3.4

Petersen, A. H. (2017). Too fat, too slutty, too loud: The rise and eeign of the unruly woman. New York: Plume.

Villarejo, A. (2013). Ethereal queer: Television, historicity, desire. London: Duke University Press. 
Wanzo, R. (2016). Precarious-girl comedy: Issa Rae, Lena Dunham, and abjection aesthetics. Camera Obscura: Feminism, Culture, and Media Studies, 31(2 (92)), 2759. https://doi.org/10.1215/02705346-3592565

Woods, F. (2015). Girls talk: Authorship and authenticity in the reception of Lena Dunham's Girls. Critical Studies in Television, 10(2), 37-54.

https:/ / doi.org/10.7227/CST.10.2.4

Woods, F. (2016). British youth television: Transnational teens, industry, genre. New York, NY: Palgrave Macmillan. 